\title{
Attached and Free-Floating Bacteria in the Fraser River Estuary, British Columbia, Canada
}

\author{
C. R. Bell and L. J. Albright* \\ Department of Biological Sciences, Simon Fraser University, Burnaby, B. C., Canada V5A IS6
}

\begin{abstract}
The contribution of free-floating bacteria versus bacteria attached to particulate material to the microbiology of the Fraser River Estuary was assessed. Approximately $60 \%$ of bacterial biomass and heterotrophic activity was associated with suspended particulates in the turbid Fraser River $10 \%$ S). The influence of attached bacteria decreased down the estuary as salinity increased dropping to $15-39 \%$ of total bacterial numbers and $4 \%$ of heterotrophic activity in the Strait of Georgia ( $26 \%$ S). Bacteria, both attached and free-floating, were the predominant part of the microbial population in the river in terms of biomass and productivity. In the Strait of Georgia, however, bacteria constituted only $4 \%$ of the microbial biomass and $25 \%$ of microbial productivity. Heterotrophic activity and productivity were stimulated in the plume $(15 \%$ S) to levels higher than those found in either the strait or the river. The percentage glucose respired was always found to be lowest in the river.
\end{abstract}

\section{INTRODUCTION}

The relative abundance of free-floating bacteria and those attached to suspended matter in aquatic environments is controversial. In the open ocean most investigators have found that the majority of the planktonic bacteria are unattached and free-floating (Wiebe and Pomeroy, 1972; Sieburth et al., 1974; Ferguson and Rublee, 1976; Azam and Hodson, 1977).

However, data from various freshwater environments vary. Rieman (1978) observed 50-93\% of glucose uptake activity passed through a $1.0 \mu \mathrm{m}$ Nuclepore filter; however, these percentage values varied with the seasons. Burnison (1975) found $82 \%$ of the bacterial biomass passed through a $1.0 \mu \mathrm{m}$ Nuclepore filter in samples from the Bay of Quinte. Berman and Stiller (1977) noted $90 \%$ of carbon uptake in the filtrate from a $3.0 \mu \mathrm{m}$ Nuclepore filtration of Lake Kinneret water.

Within estuaries the situation may be even more complex because of the changing physicochemical and biological reactions which occur as the fresh river water meets the sea water. Unfortunately literature on bacterial attachment to solid surfaces in estuaries is scarce. Darnell (1967) and Odum and de la Cruz (1967)

\footnotetext{
- Addressee for reprint requests
}

noted the importance of detritus with its attached microflora to the dynamics of several estuaries.

Accordingly, we report herein upon biomasses, heterotrophic activities and productivities of free-floating and attached bacteria within the estuary of the Fraser River through its plume into the saline waters of the Strait of Georgia.

\section{MATERIALS AND METHODS}

Samples were collected from the Fraser River Estuary on 6 cruises over a period of 13 months (Table 1). Three stations only were examined during the first 5 cruises. The 'river' station was situated approximately $40 \mathrm{~km}$ upstream from the river mouth and the salinity was always $0 \% \mathrm{~S}$ (Station 10, Fig. 1). Surface water $(1 \mathrm{~m})$ at $15 \% \mathrm{~S}$ was chosen as the plume station. This location varied between Stations 1 and 4 (Fig. 1) depending on the tide and discharge volume of the river. The 'strait' station constituted the third and last location lying in the Strait of Georgia midway between Vancouver and Nanaimo (Station SG, Fig. 1). The salinity here at $1 \mathrm{~m}$ depth varied from $25 \%$ to $26 \% \mathrm{~S}$. Water samples were taken at varying states of the tide on this 3 station design. A transect was run down the 


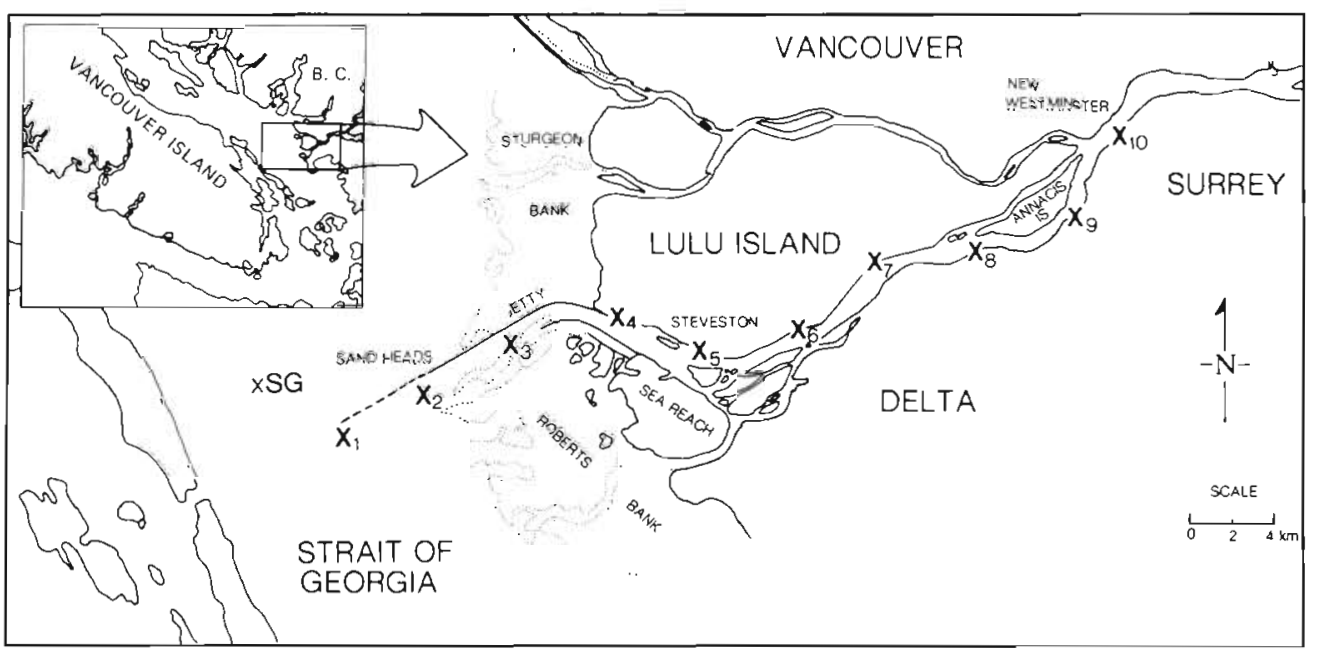

Fig. 1. Fraser River Estuary with sampling stations

river, however, for Cruise 6. Ten Stations, $5 \mathrm{~km}$ apart, were sampled on the ebb tide (Fig. 1). Water was taken at all stations at a depth of $1 \mathrm{~m}$ in a 7-1 Van Dorn bottle.

Salinity and temperature were immediately determined with a Y. S. I. Salinometer Model S-C-T 33. Total suspended solids were assayed by two techniques. (1) The total number of particulates, in the

Table 1. Cruise details

\begin{tabular}{|llc|}
\hline 1 & C.N.A.V. Endeavour & 26 March 1979 \\
2 & M.S.S.V John Strickland & 1 May 1979 \\
3 & M.S.S.V Pandora II & 16 July 1979 \\
4 & M.S.S.V Pandora II & 4 Sept. 1979 \\
5 & C.S.S. Vector & 25 Feb. 1980 \\
6 & M.S.S.V Pandora II & 8 April 1980 \\
\hline
\end{tabular}

diameter size range $1.6 \mu \mathrm{m}$ to $30.0 \mu \mathrm{m}$, were counted using a Coulter Counter TA II fitted with a $100 \mu \mathrm{m}$ diameter aperture. The samples were filtered through a $30 \mu \mathrm{m}$ Nitex mesh before counting. (2) The total weight of seston in the waters was estimated by filtering a known volume of water through a pre-dried and tared GFC filter. The filter was then drived for $24 \mathrm{~h}$ at $60^{\circ} \mathrm{C}$ and reweighed. Turbidity was assessed as absorbance at $410 \mathrm{~nm}$, against a distilled water blank, on a Spectronic 20 colorimeter (Bausch \& Lomb).

Particulate organic carbon (POC) was defined as the organic carbon retained on a GFF filter, previously baked for $24 \mathrm{~h}$ at $500{ }^{\circ} \mathrm{C}$. The filtrate was considered to be dissolved organic carbon (DOC). POC was determined using a Perkin Elmer Elemental Analyser 240. DOC was determined using the dry combustion technique of Gordon and Sutcliffe (1973) as modified for low carbon quantities by Yang and Tuominen (personal communication). A small lyophilized sample was combusted at $750^{\circ} \mathrm{C}$ in a $100 \% \mathrm{O}_{2}$ atmosphere and the
$\mathrm{CO}_{2}$ produced was then detected in a modified I. $\mathrm{R}$. Gas Analyser.

Chlorophyll a was determined spectrophotometrically after acetone extraction (Strickland and Parsons, 1968). Adenosine triphosphate (ATP) was extracted and analysed using the technique described by HolmHansen and Booth (1966). ATP was converted to microbial carbon using a multiplication factor of 250 as recommended by Holm-Hansen (1973). Total bacterial numbers were estimated by the Acridine Orange Direct Count (AODC) method as described by Hobbie et al. (1977). Estimates of bacterial carbon were derived by multiplying total counts by the mean figure for the mass of a bacterial cell in the estuary (viz: 11.13 $\mathrm{fg} \mathrm{C}$ cell $^{-1}$ ). This figure was acquired by random assays using the lipopolysaccharide technique of Watson et al. (1977). Bacteria attached to particles were distinguished from freely suspended bacteria by removing the bulk of the particles through size fractionation. One 1 of water sample was gently filtered, (at ambient pressure) through a $142 \mathrm{~mm}$ diameter, $1.0 \mu \mathrm{m}$ pore size Nuclepore placed in an Amicon Model 2000 High Flow Stirred Filter Cell (Amicon Corp., Lexington, Mass.). The water was stirred during filtration to minimize filter clogging. The salinity optima of the saprophytic bacteria were estimated by spreadplating samples on ZoBell's $2216 \mathrm{E}$ agar plates amended with $0 \%$, $15 \%$ and $30 \% \mathrm{NaCl}$. Samples were also serially diluted in 9 ml water blanks of $0 \%, 15 \%$ and $30 \% \mathrm{~S}$ corresponding to the salinity of the plate to be inoculated.

Heterotrophic activity was determined by the method described by Azam and Holm-Hansen (1973). Tritiated glucose $\left(\mathrm{D}-\left[6-{ }^{3} \mathrm{H}\right]\right.$ glucose, specific activity $30 \mathrm{Ci} \mathrm{mmol}{ }^{-1}$, New England Nuclear) was diluted with sterile distilled water to give a working concentration of $10 \mu \mathrm{Ci} \mathrm{mi} l^{-1}$. Volumes of this solution, in the range 10 to $150 \mu \mathrm{l}$, were added to $10 \mathrm{ml}$ of water sample in a 
plastic disposable syringe (Dietz et al., 1976). The samples were then incubated in the dark for $1 \mathrm{~h}$ at in situ temperature. At the end of this period the water was filtered through $0.22 \mu \mathrm{m}$ pore size Millipore filters, rinsed with $10 \mathrm{ml}$ sterile isotonic water and the filters then placed in $10 \mathrm{ml}$ PCS II scintillation fluor (Amersham Corp.). After the filters had clarified and partially dissolved the samples were counted on a Beckmann LS 8000 scintillation counter. Quenching was corrected for by the external standards ratio method.

Size fractionation of heterotrophic activity was performed by post-filtration of water samples in the above method. When incubation was complete, the samples were first filtered through $1.0 \mu \mathrm{m}$ pore size Nuclepore filters and the filtrate saved. After rinsing, the Nuclepore filters were placed in $1 \mathrm{ml}$ Protosol in a glass scintillation vial and kept at room temperature (about $20^{\circ} \mathrm{C}$ ) until the filter was completely digested (about $15 \mathrm{~min}$ ). While digestion was proceeding the filtrate was filtered through $0.22 \mu \mathrm{m}$ Millipore filters, rinsed and placed in PCS II fluor. In order to determine the radioactivity retained by the Nuclepore filters, $10 \mathrm{ml}$ PCS II was added to the Protosol solution after digestion. The vials were left for at least 24 h before counting to allow chemoluminescence to subside. Uptake versus time was determined by adding $1 \mathrm{ml}$ of the working solution of tritiated glucose $\left(10 \mu \mathrm{Ci} \mathrm{ml} \mathrm{m}^{-1}\right)$ to $1000 \mathrm{ml}$ of water sample. $10 \mathrm{ml}$ aliquots were removed every $15 \mathrm{~min}$ and treated as above.

The technique for determining the percentage respiration was that developed by Wright and Hobbie (1966) and Hobbie and Crawford (1969a). D-[U- $\left.{ }^{14} \mathrm{C}\right]$ glucose (specific activity $336 \mathrm{mCi} \mathrm{mmol}^{-1}$; Amersham Corp.), diluted to $10 \mu \mathrm{Ci} \mathrm{ml} l^{-1}$, was added to $5 \mathrm{ml}$ water samples in $25 \mathrm{ml}$ Erlenmeyer flasks fitted with serum stoppers and fluted Whatman filter paper in small suspended cups. Only one concentration of glucose
$(50 \mu 1)$ was added in these experiments. The flasks were incubated, with shaking, for $1 \mathrm{~h}$ in the dark at the in situ temperature. The reaction was stopped with $0.2 \mathrm{ml} 2 \mathrm{M} \mathrm{H}_{2} \mathrm{SO}_{4}$. The ${ }^{14} \mathrm{CO}_{2}$ emitted was trapped on the Whatman filter paper soaked with $0.2 \mathrm{ml}$ phenethylamine. The water was filtered through $0.22 \mu \mathrm{m}$ Millipore filters. Both Millipore and Whatman filters were placed in PCS II fluor and radioactivity determined as before.

An estimate of heterotrophic productivity was attempted by measuring the dark uptake of ${ }^{14} \mathrm{CO}_{2}$ as described by Romanenko et al. (1972) at in situ temperature. Sodium bicarbonate, $\left[{ }^{14} \mathrm{C}\right]$-(specific activity $8.4 \mathrm{mCi} \mathrm{mmol}{ }^{-1}$, New England Nuclear), specially packaged as $5 \mu \mathrm{Ci}$ in $1 \mathrm{ml}$ in sealed glass ampoules, was used. The contents of one ampoule were added to $240 \mathrm{ml}$ water sample in blacked-out glass bottles. The bottles were then incubated at in situ temperature for 20-24 h. At the end of the incubation period test samples were treated with $2 \% \mathrm{v} / \mathrm{v}$ formaldehyde, filtered through $0.22 \mu \mathrm{m}$ Millipore filters, rinsed with $20 \mathrm{ml}$ sterile isotonic water and counted in PCS II fluor.

Primary production of the samples was determined in a similar manner using light bottles. Incubation was for a period of $4 \mathrm{~h}$ between 1000 and $1500 \mathrm{~h}$. Total inorganic carbon values of the water samples were determined by the gas stripping technique of Stainton (1973). One $\mu \mathrm{m}$ filtrate samples for productivity measurements were pre-filtered through the Amicon Filter Cell.

Control samples, treated with $2 \% \mathrm{v} / \mathrm{v}$ formaldehyde, were run together with test samples for all the radiotracer determinations of activity and productivity. Water for all heterotrophic activity and productivity determinations were first filtered through a $300 \mu \mathrm{m}$ Nitex screen. All values reported are the average of triplicate determinations.

Table 2. Seston composition

\begin{tabular}{|c|c|c|c|c|c|c|c|c|c|}
\hline & March 79 & $\begin{array}{l}\text { River } \\
\text { May } 79\end{array}$ & Sept. 79 & March 79 & $\begin{array}{l}\text { Plume } \\
\text { May } 79\end{array}$ & Sept. 79 & March 79 & $\begin{array}{l}\text { Strait } \\
\text { May } 79\end{array}$ & Sept. 79 \\
\hline $\begin{array}{l}\text { Total particulates } \\
\text { (number } ~^{-1} \text { ) }\end{array}$ & $2.7 \times 10^{8}$ & $1.2 \times 10^{9}$ & $1.1 \times 10^{9}$ & $1.9 \times 10^{8}$ & $1.2 \times 10^{8}$ & $1.2 \times 10^{8}$ & $8.8 \times 10^{7}$ & $3.3 \times 10^{7}$ & $6.1 \times 10^{7}$ \\
\hline Seston $\left(\mathrm{mg} \mathrm{l}^{-1}\right)$ & 35 & 138 & 28 & 28 & 75 & 25 & 23 & 5 & 27 \\
\hline $\mathrm{POC}\left(m g \mathrm{I}^{-1}\right)$ & 1.48 & 2.83 & 1.04 & 1.18 & 1.30 & 1.75 & 3.88 & 1.40 & 0.96 \\
\hline $\mathrm{DOC}\left(\mathrm{mg} \mathrm{l}^{-1}\right)$ & 0.71 & 6.22 & 0.39 & 7.39 & 5.01 & 1.18 & 5.17 & 2.86 & 1.21 \\
\hline TOC $\left(\mathrm{mg} \mathrm{l}^{-1}\right)$ & 2.19 & 9.05 & 1.43 & 8.57 & 6.31 & 2.93 & 9.05 & 4.26 & 2.17 \\
\hline Percent DOC in TOC & $32 \%$ & $69 \%$ & $27 \%$ & $86 \%$ & $79 \%$ & $40 \%$ & $57 \%$ & $67 \%$ & $56 \%$ \\
\hline Chlorophyll a (mg l-1) & 0.00089 & 0.0018 & 0.00051 & 0.00084 & 0.00154 & 0.00362 & 0.01317 & 0.00613 & 0.00759 \\
\hline ATP-carbon $\left(\mu \mathrm{g} \mathrm{l}^{-1}\right)$ & - & 102 & 44 & - & 289 & 552 & - & 408 & 232 \\
\hline Bacterial-carbon $\left(\mu \mathrm{g} \mathrm{l}^{-1}\right)$ & - & 311 & 13 & - & 144 & 10 & - & 17 & 8 \\
\hline Percent bacterial C & - & $>100 \%$ & $31 \%$ & - & $50 \%$ & $2 \%$ & - & $4 \%$ & $4 \%$ \\
\hline POC: Chlorophyll a & 1663 & 1572 & 2039 & 1405 & 844 & 482 & 294 & 228 & 126 \\
\hline Percent POC in seston & $4 \%$ & $2 \%$ & $4 \%$ & $4 \%$ & $2 \%$ & $7 \%$ & $17 \%$ & $28 \%$ & $4 \%$ \\
\hline Percent ATP in POC & - & $4 \%$ & $4 \%$ & - & $22 \%$ & $32 \%$ & - & $29 \%$ & $24 \%$ \\
\hline
\end{tabular}




\section{RESULTS AND DISCUSSION}

The total suspended particulate matter in the Fraser River Estuary (Table 2) was considerable in comparison to other estuaries studied (D'Angelan and Smith, 1973; Goulder, 1977; Lenz, 1977; Eisma et al., 1978). Milliman (1980) found that the suspended matter in the Fraser River Estuary conformed to 2 patterns depending on the season. In spring and early summer (freshet time) the suspended material was largely sand grains that sedimented out rapidly in the estuary. During the remainder of the year the river had a clay and fine silt load that stayed in suspension longer. In this study the suspended matter, regardless of the time of year or whether estimated as total particulates with a Coulter Counter or as total weight of seston, decreased with distance toward the sea.

The particulate organic carbon (POC) within the seston showed strong seasonal influences. Most notable was the peak in POC during March in the Strait of Georgia. This coincides with the well documented spring phytoplankton bloom in these waters (Parsons et al., 1969). The large load of POC in the river during May undoubtedly reflected allochthonous material picked up by the heavy discharge of the freshet period (Fig. 2). The dissolved organic carbon (DOC) appeared

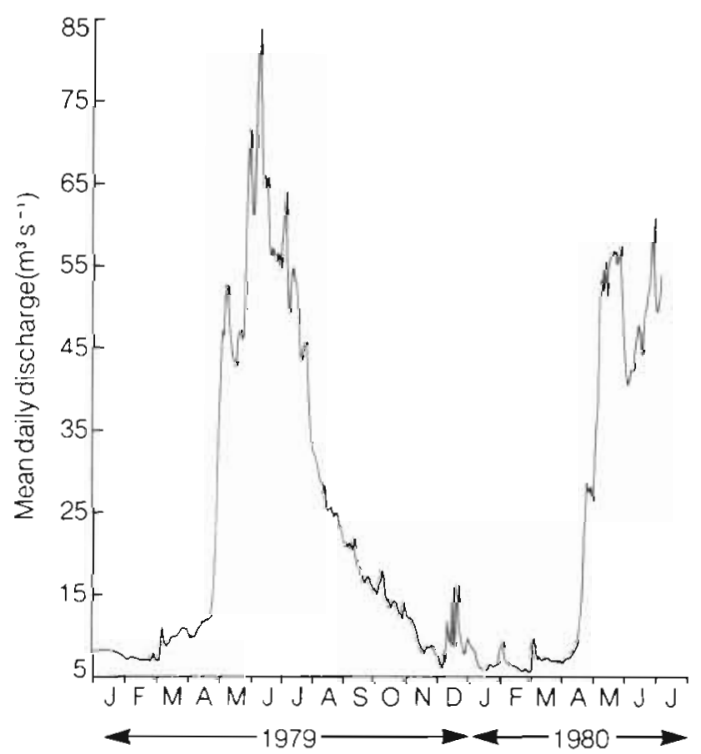

Fig. 2. Discharge volumes of the Fraser River for the period of this study

to be higher in the saline waters of the estuary. In the strait and plume DOC represented $40-80 \%$ of the total. organic carbon (TOC). Dietz et al. (1976) found similarly high values in the lower Fraser River Estuary. Except for the high value in the river during the freshet, DOC comprised less than $40 \%$ TOC.
The distribution of chlorophyll a was maximal in the Strait of Georgia. The protected waters of the strait have long been known to support large phytoplankton crops (Parsons et al., 1969; Takahashi et al., 1973; Stockner et al., 1979). The conversion of chlorophyll a to phytoplankton carbon was not attempted because of the inadvisability of such regressions (Banse, 1977). However, in May and September ATP was measured and the distribution of microbial carbon was highest in the saline waters, and corroborates the above observations on chlorophyll a. When bacterial carbon was estimated on these two cruises the converse applied. Bacterial carbon attained maximum values in the Fraser River where it accounted for $30-100 \%$ of the total microbial carbon. In the Strait of Georgia bacterial carbon constituted only $4 \%$ of the total. This compares favourably with the figure of Ferguson and Rublee (1976) for coastal waters near Cape Lookout, N. C., where the bacterial comprised $9.2 \pm 4.8 \%$ of the total plankton standing crop.

The importance of chlorophyllous carbon in the saline waters of the estuary was supported by the POC: chlorophyll a ratios as used by Weber (1973). The decline in this ratio with increasing salinity showed the increasing contribution of algal material down the estuary. Investigators who have used this ratio in water with high detritus and/or high microheterotrophs (Steele and Baird, 1965; Moss, 1970) have obtained high values similar to those occurring in the Fraser River.

The percentage of POC in the seston was low in plume and river waters but not in the strait where values of $17-28 \%$ were encountered. These high figures found in the Strait of Georgia may be peculiar to coastal waters as Zeitzschel (1970) estimated that the POC in the Gulf of California constituted $34 \%$ of the seston. Lenz (1977) also arrived at a value of $22 \%$ in the Kiel Fjord and Kiel Bight.

The amount of microbial carbon (from ATP) in the POC expressed as a percentage was also much higher in the saline waters; $22-32 \%$ in both the plume and the strait. Holm-Hansen (1973) recorded a value of $53 \%$ in coastal waters off Southern California. The lower values in these estuarine waters probably reflected the predominance of detrital carbon in the river, presumably terrestrial in origin, affecting the marine waters in the lower estuary. The data of Lenz (1977) shows similar reduced values $(9-16 \%)$ in the sheltered waters of the Kiel Bight.

Sheldon (1972) demonstrated that Nuclepore filters were superior as screens in size fractionation studies. Darnell (1967) in discussing the problem of detritus in estuaries suggested adopting $1.0 \mu \mathrm{m}$ as the critical diameter to distinguish particulate $(\geqslant 1.0 \mu \mathrm{m})$ from subparticulate $(<1.0 \mu \mathrm{m})$ detritus. Accordingly 
Table 3. Effect of size fractionation with a $1.0 \mu \mathrm{m}$ pore size Nuclepore filter (April 1980)

\begin{tabular}{|c|c|c|c|c|}
\hline & & River & Plume & Strait \\
\hline $\begin{array}{l}\text { Particles } \\
\left.\left(\mathrm{m}^{-1}\right]^{-1}\right)\end{array}$ & $\begin{array}{l}\quad \text { Total } \\
<1.0 \mu \mathrm{m} \text { flltrate } \\
\% \text { retention }\end{array}$ & $\begin{array}{c}1.5 \times 10^{6} \\
1.8 \times 10^{5} \\
88\end{array}$ & $\begin{array}{c}3.6 \times 10^{5} \\
1.4 \times 10^{4} \\
97\end{array}$ & $\begin{array}{c}7.3 \times 10^{4} \\
3.1 \times 10^{4} \\
60\end{array}$ \\
\hline $\begin{array}{l}\text { Bacteria } \\
\left(\mathrm{ml}^{-1}\right)\end{array}$ & $\begin{array}{c}\text { Total } \\
<1.0 \mu \mathrm{m} \text { filtrate } \\
\% \text { retention }\end{array}$ & $\begin{array}{c}2.1 \times 10^{6} \\
9.0 \times 10^{5} \\
57\end{array}$ & $\begin{array}{c}1.5 \times 10^{6} \\
1.2 \times 10^{6} \\
20\end{array}$ & $\begin{array}{c}9.4 \times 10^{5} \\
9.2 \times 10^{5} \\
2\end{array}$ \\
\hline $\begin{array}{l}\text { Chloro- } \\
\text { phyll a } \\
\left(\mathrm{mg} \mathrm{l}^{-1}\right)\end{array}$ & $\begin{array}{c}\text { Total } \\
<1.0 \mu \mathrm{m} \text { filtrate } \\
\% \text { retentation }\end{array}$ & $\begin{array}{c}0.00082 \\
0.00027 \\
67\end{array}$ & $\begin{array}{c}0.00162 \\
0.0002 \\
88\end{array}$ & $\begin{array}{c}0.00836 \\
0.00019 \\
98\end{array}$ \\
\hline
\end{tabular}

$142 \mathrm{~mm}$ diameter Nuclepore filters with $1.0 \mu \mathrm{m}$ pore size were tested as to their screening performance in this estuary (Table 3 ). The filters and procedure adopted, gave a consistently high retention of particles (60-80\%, counted microscopically) and chlorophyll a (67 to $98 \%$ ) at all 3 stations. However, in the strait, where most bacterial viewed under epifluorescence microscopy were free-floating, only $2 \%$ of the bacterial population was retained. The larger percentages of bacteria retained by the filter in the river and plume (57\% and $20 \%$ respectively) were therefore considered attached to particles or in aggregates. Direct counting with the microscope of the bacteria attached or in clumps agreed closely with this assumption. Microscopic examination also indicated that the filtering process did not significantly break up any of the particulate material. Unfortunately, the reproducibility of direct counting was poor and was not applicable to the heterotrophic uptake experiments. Filtering with the $1.0 \mu \mathrm{m}$ pore size Nuclepore was therefore employed as the preferred technique to separate attached from freefloating bacteria.

The total counts of bacteria (Table 4) showed the trend of an inverse relationship to salinity. The average number of bacteria in the river was $1.2 \times 10^{7} \mathrm{ml}^{-1}$ decreasing to $6.4 \times 10^{6} \mathrm{ml}^{-1}$ in the strait. Palumbo and Ferguson (1978) noted a similar inverse relationship in the Newport River Estuary. The high numbers observed in the Fraser River agree with data obtained by these authors in the upper Newport River Estuary and also with numbers in the Humber River (Goulder et al., 1980). The figures obtained in the Strait of Georgia correspond to those obtained by Ferguson and Palumbo (1979) in neritic waters off Long Island. The free-floating bacteria showed no obvious pattern in their distribution. The percentage attached bacteria, however, showed a very marked trend with the percentage attached consistently decreasing from river to
Table 4. Epifluorescent counts (Acridine Orange Direct Count)

\begin{tabular}{|c|c|c|c|c|}
\hline & Cruise & River & Plume & Strait \\
\hline $\begin{array}{l}\text { Total counts } \\
\left(\mathrm{ml}^{-1}\right)\end{array}$ & $\begin{array}{l}\text { March } 79 \\
\text { May } 79 \\
\text { July } 79 \\
\text { Feb. } 80 \\
\text { April } 80\end{array}$ & $\begin{array}{l}2.9 \times 10^{7} \\
2.8 \times 10^{7} \\
1.2 \times 10^{6} \\
1.6 \times 10^{6} \\
2.5 \times 10^{6}\end{array}$ & $\begin{array}{l}2.2 \times 10^{8} \\
1.3 \times 10^{7} \\
9.5 \times 10^{5} \\
1.2 \times 10^{7} \\
1.6 \times 10^{6}\end{array}$ & $\begin{array}{l}1.5 \times 10^{7} \\
1.6 \times 10^{6} \\
7.5 \times 10^{5} \\
1.4 \times 10^{7} \\
4.7 \times 10^{5}\end{array}$ \\
\hline $\begin{array}{l}\text { Filterate } \\
\text { counts } \\
\left.(\mathrm{m}]^{-1}\right)\end{array}$ & $\begin{array}{l}\text { March } 79 \\
\text { May } 79 \\
\text { July } 79 \\
\text { Feb. } 80 \\
\text { April } 80\end{array}$ & $\begin{array}{l}1.8 \times 10^{6} \\
2.8 \times 10^{5} \\
1.6 \times 10^{5} \\
8.4 \times 10^{5}\end{array}$ & $\begin{array}{l}5.0 \times 10^{5} \\
3.7 \times 10^{5} \\
2.9 \times 10^{6} \\
8.9 \times 10^{5}\end{array}$ & $\begin{array}{l}9.8 \times 10^{5} \\
6.1 \times 10^{5} \\
1.1 \times 10^{7} \\
4.0 \times 10^{5}\end{array}$ \\
\hline $\begin{array}{l}\text { Percentage } \\
\text { attached } \\
\text { bacteria }\end{array}$ & $\begin{array}{l}\text { March } 79 \\
\text { May } 79 \\
\text { July } 79 \\
\text { Feb. } 80 \\
\text { April } 80\end{array}$ & $\begin{array}{l}94 \% \\
77 \% \\
90 \% \\
66 \%\end{array}$ & $\begin{array}{l}96 \% \\
61 \% \\
76 \% \\
44 \%\end{array}$ & $\begin{array}{l}39 \% \\
19 \% \\
24 \% \\
15 \%\end{array}$ \\
\hline
\end{tabular}

plume to strait. The data of Goulder et al. (1980) renders a percentage attached of 90-95\% at the mouth of the Humber River (10-16\% S) decreasing to $15 \%$ at $31 \%$ S. Wright's (1978) data, using size fractionation on surface waters of the Merrimack River Estuary, show that the $>1.0 \mu \mathrm{m}$ fraction comprised $23 \%$ of the total $30 \mathrm{~km}$ upriver decreasing to $8 \%$ at the inlet.

The degree of attachment in freshwater environments varies considerably (see Introduction). Unfortunately there is a paucity of data regarding microbial attachment to particulates in rivers. Goulder (1976) compared four rivers to the Humber and found that the percent attached at the mouth of the rivers varied from 6 to $67 \%$. Jannasch (1956) found $99 \%$ of the microbial population in the Nile River attached to silt particles. Geesey and Costerton (1969) on the other hand found the majority of bacteria in the Athabasca River freefloating. The percent attached bacteria in the Humber River was positively correlated with the number of particulates (Goulder, 1976). This is probably one of many variables influencing the number of attached bacteria in river water.

The consensus of opinion is that free-floating bacteria are the norm in marine environments (see Introduction) and since the ultimate transition in an estuary is from fresh to saline water, the observations of decreasing attachment in the Fraser River Estuary may be a general phenomenon. The transect performed down the river in April 1980 confirmed these results. Saltwater intrusion was detected at Station 6 approximately $25 \mathrm{~km}$ from the mouth of the river (Fig. 3a). The temperature increased by $2-3 \mathrm{C}^{\circ}$ as the warmer marine water mixed with the river water. Suspended particulate matter, assayed as total particulate counts (Coulter 
counter) and as turbidity at $410 \mathrm{~nm}$ decreased in an almost perfectly linear fashion with distance downriver. Bacterial counts, both total and free-floating, also decreased steadily down to Station 6 (Fig. 3b). The
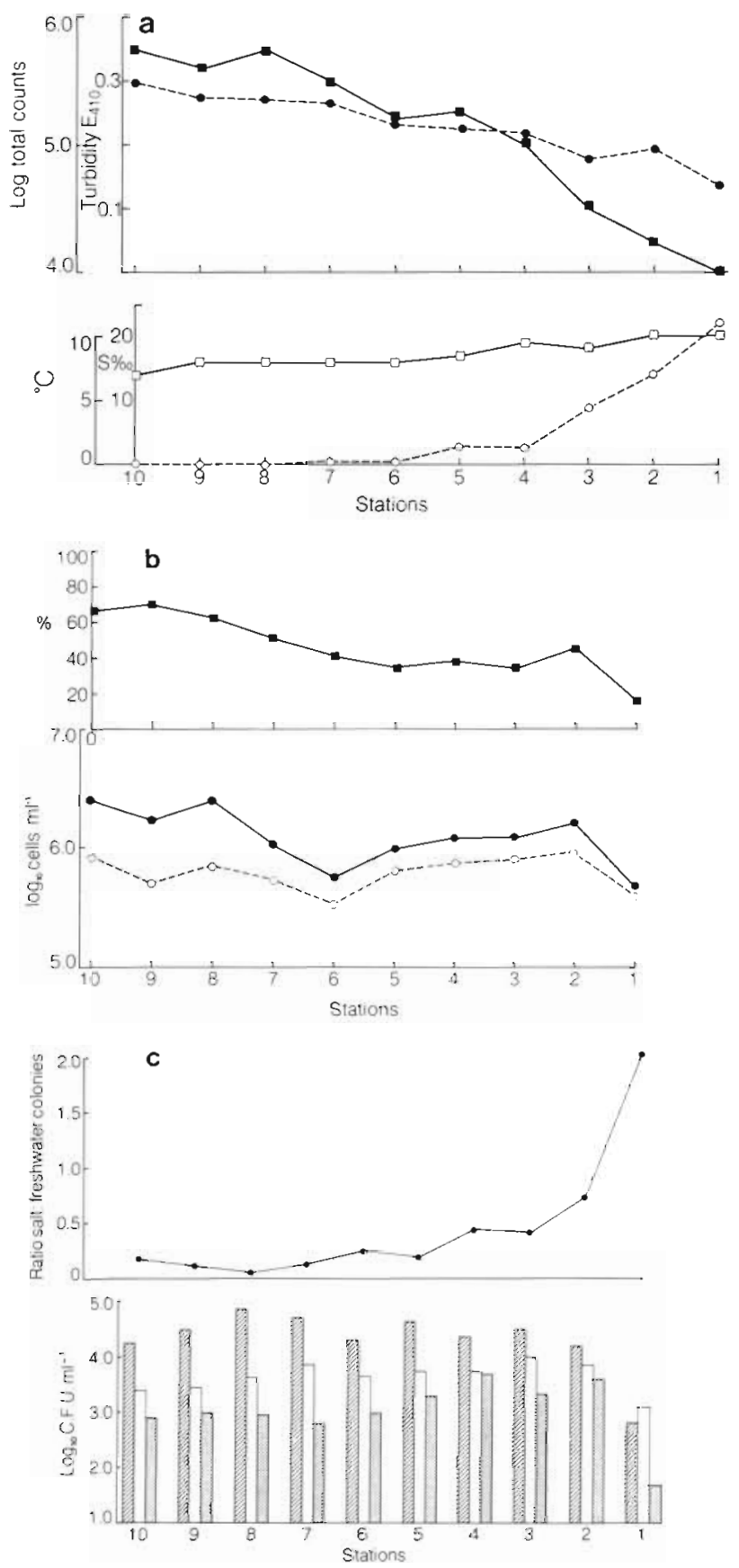

Fig. 3. Transect data. (a) Turbidity (solid squares), Coulter counts (solid circles), temperature (open squares), salinity (open circles); (b) percent attached bacterial (solid squares), total bacterial counts (solid circles), filtrate bacterial counts (open circles); (c) salinity optima of saprophytic bacteria; colony counts on $0 \% \mathrm{~S}$ agar plates (hatched bars), $15 \% \mathrm{~S}$ agar plates (open bars) and $30 \% \mathrm{~S}$ agar plates (stippled bars). Stations as shown in Fig. 1 percent attached similarly decreased down to Station 6. Fig. 3a suggests that sedimentation of particulates occurred progressively from Stations 10 to 1 with the heavier sand particles deposited sooner in the upper estuary. Since bacteria can attach to sand grains (Meadows and Anderson, 1966) it is postulated that the initial decline in percent attached bacteria upriver from the salt water intrusion was attributable to sedimenting sands grains and associated bacteria. Mitchell (1968) cites several examples where sedimentation reduces bacteria in the freshwater column as it is discharged into the sea. The increase of total counts from Stations 6 to 2 was mainly due to increases in the numbers of free-floating bacteria. Numerous factors could influence the increases in the number of freefloating bacteria viz, stimulation in growth, desorption from particles, resuspension from the sediment or immigration from marine waters. The immigration of predominately free-floating bacteria from the Strait of Georgia into the estuary certainly occurred. The origin of the bacterial populations was assessed by salinity optima determinations (Fig. 3c). Colonies with $0 \%$ salinity preference were most abundant from Stations 10 to 2. However if the histograms are expressed as the ratio of salt to freshwater tolerant colonies this ratio climbs exponentially from Stations 6 to 1 . Seki et al. (1969) observed a similar decline in the proportion of fresh to saltwater colonies in the Nanaimo River Estuary. Albright (1977) showed that the bacterial populations in the Strait of Georgia favoured marine agar plates of $26 \% \mathrm{~S}$. The increase in the ratio of salt: freshwater colonies demonstrates the influx of bacterial from the strait into the lower estuary. The river bacteria cannot therefore be considered as the sole input of bacteria into the estuary. Roper and Marshall (1979) fund that the adsorption-desorption of Escherichia coli to suspended particulates to be dependent on the salinity in the Tamar River Estuary. Adsorption-desorption processes are most probably operating in the Fraser River Estuary as well. Grieve and Fletcher (1977) have already demonstrated heavy metal desorption from particulates in the brackish region of the Fraser River Estuary.

Fig. 4 clearly shows the stimulation in glucose uptake by bacteria in plume water compared to the parent waters of the strait and river. Valdes (1980) investigated the Fraser River Estuary at the same time as this study (1979-80) and also found maximum glucose uptake in water of $15 \% \mathrm{~S}$. Seki et al. (1969) in their study of the Nanaimo River Estuary, which also empties into the Strait of Georgia, encountered maximum uptake of glucose in $20 \% \mathrm{~S}$ water. In the Humber River Estuary, Goulder et al. (1980) likewise found increased heterotrophic activity, at East Clough where the mean salinity was $10 \%$ S. Estuarine waters 


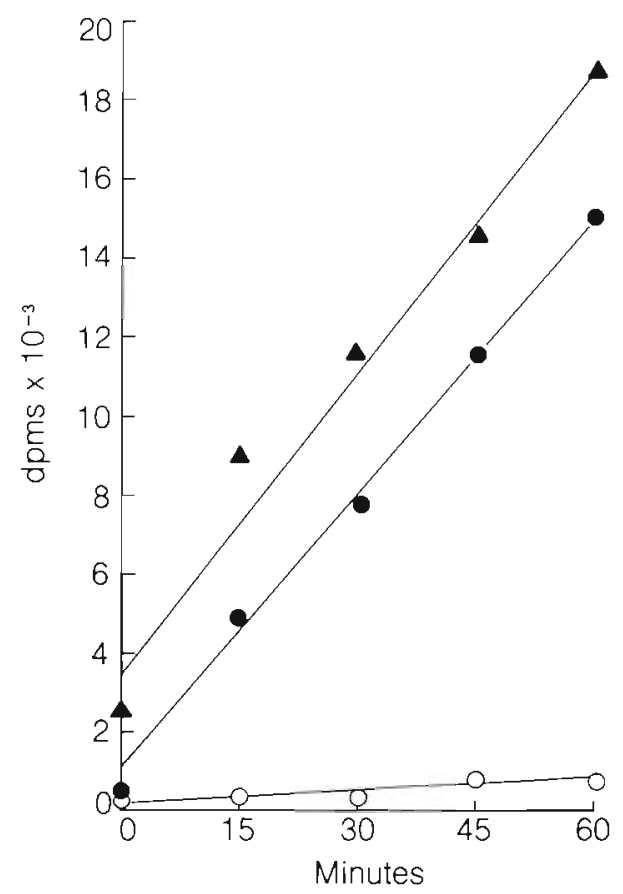

Fig. 4. Uptake o: ${ }^{3} \mathrm{H}$-glucose with time. Plume sample (solid triangles), strait sample (solid circles) and river sample (open circles)

of intermediate salinity where fresh and salt water mix therefore appear to provide a favourable regime for heterotrophic bacterial activities. Stevenson and Erkenbrecher (1976) in a review on estuarine bacteria found the heterotrophic potential of these cells, as recorded by several authors in selected estuaries, sig- nificantly greater than values obtained in ocean or freshwater environments.

The freshet period upset the determination of heterotrophic activity in May (Table 5a). In March and February, however, turnover time was quite slow in the river and was accelerated in the plume. Despite these slow turnover times in the river the heterotrophic potential $V_{\text {max }}$, was comparatively high. A comparison of the kinetic parameters obtained for heterotrophic uptake in the Fraser River Estuary with other estuaries and coastal waters is shown in Table 6 . The values published on the Fraser River system since 1973 are all in good agreement and are amongst the lowest recorded in the literature. $V_{\max }$ values $\geqslant 10 \mu \mathrm{g}$ glucose $\mathrm{l}^{-1} \mathrm{~h}^{-1}$ occur in obviously polluted areas (Toronto Harbour, Tokyo Bay), salt marsh estuaries (Sapelo Island) and more eutrophied estuaries (Nanaimo River, Pamlico River). The Fraser River estuary is less bacteriologically active and compares with the Humber and Elbe estuaries.

When ${ }^{14} \mathrm{C}$-glucose was used as substrate (Table 5b) the plume unequivocally supported the maximum uptake in both assimilated glucose and respired glucose. However, the river populations have a consistently lower percent respiration than the plume or strait. Hanson and Wiebe (1977) observed a similar rise in percentage respiration with distance offshore from the Altamaha River and also along a transect from Doboy Sound entrance. Hoppe (1978) reviewed the respiration ratios reported in the literature, i. e. the ratio of the substrate respired to the total uptake

Table 5. Heterotrophic activity. Uptake expressed as pg glucose $\mathrm{l}^{-1} \mathrm{~h}^{-1}$. Percent respiration calculated as respired uptake divided by total uptake

(a) ${ }^{3} \mathrm{H}$-glucose uptake. (After Azam and Holm-Hansen, 1973)

\begin{tabular}{|c|c|c|c|c|c|c|c|c|c|}
\hline \multirow[t]{2}{*}{ Cruise } & \multicolumn{3}{|c|}{ River } & \multicolumn{3}{|c|}{ Plume } & \multicolumn{3}{|c|}{ Strait } \\
\hline & $\mathrm{T}$ & $V_{\max }$ & $\mathrm{Kt}+\mathrm{Sn}$ & $\mathrm{T}$ & $V_{\max }$ & $\mathrm{Kt}+\mathrm{Sn}$ & $\mathrm{T}$ & $V_{\max }$ & $\mathrm{Kt}+\mathrm{Sn}$ \\
\hline March 1979 & 106 & 0.044 & 4.64 & 21 & 0.40 & 8.39 & 15 & 0.096 & 1.39 \\
\hline May 1979 & 17 & 0.028 & 0.475 & \multicolumn{3}{|c|}{ (non-linear uptake) } & 26 & 0.0069 & 0.18 \\
\hline Feb. 1980 & 104 & 0.0071 & 0.745 & 57 & 0.0034 & 0.192 & 145 & 0.0014 & 0.196 \\
\hline
\end{tabular}

$\mathrm{T}=$ Turnover time in hours $\quad \mathrm{V}_{\mathrm{ndx}}$ expressed in $\mu \mathrm{g}$ glucose $\mathrm{l}^{-1} \mathrm{~h}^{-1} \quad \mathrm{Kt}+\mathrm{Sn}$ expressed in $\mu \mathrm{g}$ glucose $\mathrm{I}^{-1}$

(b) ${ }^{14} \mathrm{C}$-glucose uptake. (After Hobbie and Crawford, 1969a)

\begin{tabular}{|c|c|c|c|c|c|c|}
\hline Cruise & Site & Salinity & Assimilated & Respired & Total & $\begin{array}{l}\text { Percent } \\
\text { respiration }\end{array}$ \\
\hline \multirow[t]{3}{*}{ July 1979} & River & $0 \%$ & 55 & 18 & 73 & $25 \%$ \\
\hline & Plume & $16 \%$ & 164 & 128 & 292 & $44 \%$ \\
\hline & Strait & $26 \%$ & 88 & 44 & 132 & $33 \%$ \\
\hline \multirow[t]{3}{*}{ Sept. 1979} & River & $0 \%$ & 75 & 39 & 114 & $34 \%$ \\
\hline & Plume & $14 \%$ & 118 & 115 & 233 & $49 \%$ \\
\hline & Strait & $26 \%$ & 65 & 81 & 146 & $55 \%$ \\
\hline
\end{tabular}


Table 6. Comparison of heterotrophic uptake parameters in estuarine and coastal waters

\begin{tabular}{|c|c|c|c|c|c|}
\hline Source & Study area & Isotope & $\begin{array}{c}V_{\max } \\
\left(\mu g \text { glucose } l^{-1} h^{-1}\right)\end{array}$ & $\begin{array}{l}\mathrm{T} \\
(\mathrm{h})\end{array}$ & $\begin{array}{c}\text { Kt }+S n \\
\left(\mu g \text { glucose } I^{-1}\right)\end{array}$ \\
\hline Hobbie and Crawford (1969b) & Pamlico River Estuary & ${ }^{14} \mathrm{C}$ & $3.25-9.5$ & & \\
\hline Crawford et al. (1974) & Pamlico River Estuary & ${ }^{14} \mathrm{C}$ & $0.15-24.1$ & $0.2-22$ & $0.83-49.9$ \\
\hline Vaccaro and Jannasch (1966) & Woods Hole Dock & ${ }^{14} \mathrm{C}^{\cdot}$ & 0.275 & & 1.6 \\
\hline Seki et al. (1969) & Nanaimo River Estuary & ${ }^{14} \mathrm{C}^{\cdot}$ & $0.187-1.56$ & & \\
\hline Wood and Chua (1973) & Toronto Harbour & ${ }^{14} \mathrm{C}$ & $0.51-10.59$ & $12-304$ & $20-371$ \\
\hline Seki et al. (1975) & Tokyo Bay & ${ }^{14} \mathrm{C}$ & 18 & 8.7 & 155 \\
\hline & Shimoda Bay Estuary & & 23 & 31 & 710 \\
\hline $\begin{array}{l}\text { Goulder (1976, 1977) } \\
\text { Goulder et al. }(1979,1980)\end{array}$ & Humber River Estuary & ${ }^{14} \mathrm{C}^{+}$ & $0.007-2.6$ & $2-402$ & $5.4-30.3$ \\
\hline Wright and Shah (1975) & Booth Bay & ${ }^{14} \mathrm{C}$ & 0.44 & 29 & 13 \\
\hline Wright (1978) & Esse River Estuary & ${ }^{14} \mathrm{C}$ & $0.016-1.31$ & & \\
\hline Gocke (1977) & Kiel Fjord & ${ }^{14} \mathrm{C}^{*}$ & $0.06-1.66$ & $3-36$ & $1.85-11.75$ \\
\hline Hoppe (1978) & Elbe River Estuary & ${ }^{3} \mathrm{H} \cdot$ & $0.033-0.113$ & $16-37$ & $0.94-1.98$ \\
\hline Hanson and Wiebe (1977) & Sapelo Island & ${ }^{14} \mathrm{C}$ & $0.35-78$ & $1.2-13.5$ & \\
\hline Delattre et al. (1979) & Gravelines & ${ }^{14} \mathrm{C}$ & $0.0015-1.04$ & $6-1000$ & \\
\hline Albright and Wentworth (1973) & Fraser River & ${ }^{14} \mathrm{C}$ & $0.0135-0.049$ & $2-17$ & $156-347$ \\
\hline Dietz et al. (1976) & Fraser River Estuary & ${ }^{14} \mathrm{C}$ & $0.0038-0.088$ & $50-6000$ & $0.5-19$ \\
\hline Albright (1977) & Fraser River Estuary & ${ }^{14} \mathrm{C}$ & $0.002-0.9$ & $10-1750$ & $1.0-21.5$ \\
\hline Valdes $(1980)$ & Fraser River Estuary & ${ }^{3} \mathrm{H} \cdot$ & $0.01-5.0$ & $12-120$ & $0.01-40$ \\
\hline $\begin{array}{l}\text { Bell and Albright } \\
\text { (this publication) }\end{array}$ & Fraser River Estuary & ${ }^{3} \mathrm{H}^{\cdot}$ & $0.0014-0.4$ & $15-145$ & $0.18-8.39$ \\
\hline
\end{tabular}

(assimilated and respired), and observed that the ratio for a given substrate appeared constant and independent of water temperature. Ratios for 17 amino-acids plus glucose by Crawford et al. (1974) appear to support the notion of constancy in the Pamlico River Estuary. Hobbie and Crawford (1969a) suggested that the percentage respired of a substrate was a function of its metabolic proximity to the T.C.A. cycle. Several investigations seems to question this however. Berman et al. (1979) observed higher respiration percentages of glucose in the summer than in the winter in Lake Kinneret and suggested that respiration was influenced by the nature of the indigenous population as well as by temperature. Tison and Pope (1980) demonstrated the effect of temperature shifts on the respiration ratios of bacteria using pure cultures and natural populations. Burnison and Morita (1974) noted seasonal changes in the respiration ratios in Upper Klamath Lake. They favoured seasonal shifts in the populations of heterotrophic bacteria as the most likely explanation. Griffiths et al. (1978) noted that in the Beaufort Sea, the percentage respiration of glutamic acid was higher in the winter than in the summer. Because the water temperature in this part of the Arctic Ocean varies by only $2-3 C^{\circ}$ seasonally, it was postulated that nutrients may cause the change. Carney and Colwell (1976) and Wood and Chua (1973) established a positive correlation between percentage respiration and pollution levels in Baltimore Harbor and
Toronto Harbor respectively. The observations may, however, have been more strictly applicable to levels of eutrophication in these harbours as Goulder et al. (1979) found respiration ratios unsuitable as indicators of copper pollution in the Humber Estuary.

The many factors cited above as capable of influencing respiration ratios, e.g. changes in temperature, nutrients and population composition, occur in the Fraser River Estuary. However, it is believed that the most significant influence causing the percent respiration increase between river and plume in the Fraser River Estuary was the increasing salinity. Konings and Veldkamp (1980) cite a shift from freshwater to seawater as a major environmental influence on the protonmotive force of a bacterium's cell membrane. According to this theory, the extrusion of undesirable sodium ions accumulating in the cell due to increasing $\mathrm{NaCl}$ concentrations in the external medium, will occur in antiport with protons. The decrease in proton-motive force will have to be offset by a translocation of protons from the cytoplasm to the outer side of the membrane through cytochrome-lined electron transfers and ATP hydrolysis. Watson (1970) demonstrated an increase in the maintenance energy of yeast cells with increasing salinity. It may be that percent respiration increased to fuel these processes

The contribution of attached and free-floating bacterial to heterotrophic activity (Table 7 ) paralleled the observed distribution in bacterial numbers. Approxi- 
Table 7. Heterotrophic activity with particle size fractionation (February 1980)

\begin{tabular}{|c|c|c|c|c|c|}
\hline $\begin{array}{l}\text { Size } \\
\text { class }\end{array}$ & Site & Turnover ${ }^{\circ}$ & $V_{\max } \cdot$ & $K t+S n$ & $\begin{array}{l}\text { Percent } \\
\text { of total }\end{array}$ \\
\hline \multirow[t]{3}{*}{$\geqslant 1.0 \mu \mathrm{m}$} & River & 165 & 0.000312 & 0.514 & $63 \%$ \\
\hline & Plume & 639 & 0.000884 & 0.565 & $9 \%$ \\
\hline & Strait & 4090 & 0.000774 & 3.16 & $4 \%$ \\
\hline \multirow[t]{3}{*}{$<1.0 \mu \mathrm{m}$} & River & 292 & 0.0102 & 2.99 & $36 \%$ \\
\hline & Plume & 63 & 0.00278 & 0.174 & $90 \%$ \\
\hline & Strait & 161 & 0.00149 & 0.24 & $90 \%$ \\
\hline \multirow[t]{3}{*}{ Total } & River & 104 & 0.00712 & 0.745 & \\
\hline & Plume & 57 & 0.00335 & 0.192 & \\
\hline & Strait & 145 & 0.00135 & 0.196 & \\
\hline
\end{tabular}

mately $60 \%$ of the activity, measured as turnover time, was associated with the particle fraction in the river whereas in the plume and strait, activity of the attached bacteria diminished to less than $10 \%$ of the total. Although $36 \%$ of the turnover time resided with the free-floating bacteria in the river, the $V_{\max }$ obtained was very large. The number of free-floating bacteria in the river was relatively low $\left(1.6 \times 10^{5}\right)$ so this cannot explain the high $V_{\max }$. It may be that the potential in the river was high yet some form of nutrient limitation retarded the turnover time.

The transition to free-floating bacteria and associated heterotrophic activity typical of open ocean waters (see Introduction) appeared to occur much closer inshore in the Fraser River Estuary than has been observed in other estuaries. Goulder (1976) for instance found the $V_{\max }$ of the attached bacteria consistently greater than the $V_{\max }$ of the free-floating bacteria in the Humber River at Hull (mean salinity $16 \%$ S). Hanson and Wiebe (1977) found $>70 \%$ of the bacterial activity associated with very large particle fractions $(>180 \mu \mathrm{m})$ up to $5 \mathrm{~km}$ offshore from Sapelo Island.

The data on bacterial productivity were treated with caution due to extensive criticism of the Romanenko technique (Overbeck and Daley, 1973; Banse, 1974; Fuhrman and Azam, 1980). The size fractionation experiment performed on the September cruise (Table 8a) showed that the dark uptake of ${ }^{14} \mathrm{CO}_{2}$ with unfiltered water was identical to the uptake in filtered water in the light and in the dark. Dark uptake was therefore mediated through bacterial activity in Fraser River Estuary waters. Apart from the high figure of dark $\mathrm{CO}_{2}$ uptake in the strait in March (spring phytoplankton bloom), maximum values occurred in the plume (Table $8 \mathrm{~b}$ ). Estimates of productivity are given as a range fo acknowledge the observation of Overbeck and Daley (1973) that dark $\mathrm{CO}_{2}$ uptake can represent between $1 \%$ and $12 \%$ of bacterial production. The most conservative estimate of production (dark uptake as $12 \%$ ) produced values comparable to those obtained in Saanich Inlet, B. C. $\left(7.2-47 \mu \mathrm{g} \mathrm{Cl}^{-1} \mathrm{~d}^{-1}\right)$ using thymidine incorporation (Fuhrman and Azam, 1980). When compared to photosynthetic production in September, these conservative estimates give ratios for bacterial: photosynthetic production of $3.1: 1$ (river), $0.6: 1$ (plume) and $0.25: 1$ (strait). Bacteria were therefore the major contributors to microbial production in the river but their significance declined in the plume and strait. Bacterial production in the Strait of Georgia constituted $25 \%$ of photosynthetic production and agrees with the estimates of Derenback and Williams (1974) in the Solent and English Channels where bacterial production was $1-30 \%$ of photosynthetic production.

Table 8. Dark ${ }^{14} \mathrm{CO}_{2}$ uptake $\left(\mu \mathrm{g} \mathrm{C} \mathrm{l}^{-1} \mathrm{~d}^{-1}\right)$

(a) Particle size fractionation (Sept. 1979)

\begin{tabular}{lccrr}
\hline & & River & Plume & Strait \\
\hline Light & Unfiltered & 7.4 & 71.5 & 167.5 \\
incubations & $<1.0 \mu \mathrm{m}$ filtrate & 2.5 & 5.1 & 6.0 \\
Dark & Unfiltered & 2.7 & 5.4 & 5.0 \\
incubations & $<1.0 \mu \mathrm{m}$ filtrate & 2.5 & 5.4 & 5.6
\end{tabular}

(b) Uptake (unfiltered water) and productivity estimates $\left(\mu \mathrm{gC}^{-1} \mathrm{~d}^{-1}\right)$. Numbers in brackets: estimates of heterotrophic production of bacterial carbon based on dark $\mathrm{CO}_{2}$ uptake respresenting $1 \%$ to $12 \%$ of production

\begin{tabular}{lccc}
\hline Cruise & River & Plume & Strait \\
\hline March 1979 & 1.38 & 2.30 & 10.79 \\
& $(138-11)$ & $(230-26)$ & $(1079-90)$ \\
May 1979 & 2.36 & 2.86 & 1.54 \\
& $(236-20)$ & $(286-24)$ & $(154-13)$ \\
Sept. 1979 & 2.72 & 5.39 & 5.00 \\
& $(272-23)$ & $(539-45)$ & $(500-42)$ \\
\hline
\end{tabular}

Acknowledgement. The authors acknowledge the financial support of the National Research Council of Canada.

\section{LITERATURE CITED}

Albright, L. J., Wentworth, J. W. (1973). Use of the heterotrophic activity technique as a measure of eutrophication. Environ. Pollut. 5 (1): 59-72

Albright, L. J. (1977). Heterotrophic bacterial dynamics in the lower Fraser River, its estuary and Georgia Strait, B. C., Canada. Mar. Biol. 39: 203-211

Azam, F., Hodson, R. E. (1977). Size distribution and activity of marine microheterotrophs. Limnol. Oceanogr. 22 (3): 492-501 
Azam, F., Holm-Hansen, O. (1973). Use of tritiated substrates in the study of heterotrophy in seawater Mar Biol. 23: $191-196$

Banse, K. (1974). On the role of bacterioplankton in the tropical ocean. Mar Biol. 24:1-5

Banse, K. (1977). Determining the carbon-to-chlorophyll ratio of natural phytoplankton. Mar. Biol. 41: 199-21.2

Berman, T., Stiller, M. (1977). Simultaneous measurement of phosphorus and carbon uptake in Lake Kinneret by multiple isotopic labelling and differential filtration. Microb. Ecol. 3: 279-288

Berman, T., Hadas, O., Marcham, U. (1979). Heterotrophic glucose uptake and respiration in Lake Kinneret. Hydrobiol. 62 (3): 275-282

Burnison, K. B., Morita, R. Y (1974). Heterotrophic potential for amino acid uptake in a naturally eutrophic take. Appl. Microbiol. 27 (3): 488-495

Burnison, B. K. (1975). Microbial ATP studies. Verh. int. Verein. theor angew. Limnol. 19: 286-290

Carney, J. F., Colwell, R. R. (1976). Heterotrophic utilisation of glucose and glutamate in an estuary: Effect of season and nutrient load. Appl. environ. Microbiol 31 (2): $227-233$

Crawford, C. C., Hobbie, J. E., Webb, K. L. (1974). The utilization of dissolved free amino acids by estuarine microorganisms. Ecology 55: 551-563

D'Anglejan, B. F., Smith, E. C. (1973). Distribution, transport and composition of suspended matter in the St. Lawrence Estuary. Can. J Earth Sci. 10: 1380-1396

Darnell, R. M. (1967). Organic detritus in relation to the estuarine ecosystem. In: Lauff, G. H. (ed.) Estuarıes. Publs Am. Ass. Advmt Sci. 83: 376-382

Delattre, J. M., Delesmont, R., Clabaux, M., Oger, C., Leclerc, H. (1979). Bacterial biomass, production and heterotrophic activity of the coastal seawater at Gravelines (France). Oceanolog. Acta 2 (3): 317-324

Derenbach, J. B., Williams, P. J. LeB. (1974). Autotrophic and bacterial production. Fractionation of plankton populations by differential filtration of samples from the English Channel. Mar. Biol. 25: 263-269

Dietz, A. S., Albright, L. J., Tuominen, T (1976). Heterotrophic activities of bacterioneuston and bacterioplankton. Can. J Microbiol. 22: 1699-1709

Eisma, D., Kalf, J., Van Der Eaast, S. J. (1978). Suspended matter in the Zaire Estuary and the adjacent Atlantic Ocean. Netherlands J Sea Res. 12 (3/4): 382-406

Ferguson, R. L., Rublee, P. (1976). Contribution of bacteria to standing crop of coastal plankton. Limnol. Oceanogr 21. $141-144$

Ferguson, R. L., Palumbo, A. V (1979). Distribution of suspended bacteria in neritic waters south of Long Istand during stratified conditions. Limnol. Oceanogr 24 (4): $697-705$

Fuhrman, J. A., Azam, F. (1980). Bacterioplankton secondary production estimates for coastal waters of British Columbia, Antarctica and California. Appl. environ. Microbiol. 39 (6) : 1085-1095

Geesey, G. G., Costerton, J. W. (1979). Microbiology of a northern river: bacteria] distribution and relationship to suspended sediment and organic carbon. Can. J Microbiol. 25: 1058-1062

Gocke, K. (1977). Heterotrophic artivity. In: Rheinheimer, G. (ed.) Microbial ecology of a brackish water cnvironment. Springer-Verlag, Heidelberg, pp. 198-222

Gordon, D. C., Jr., Suttcliffe, W. H., Jr (1973). A new dry combustion method for the simultaneous determination of total organic carbon and nitrogen in seawater. Mar. Chem. 1: $231-244$

Goulder, R. (1976). Relationships between suspended solids and standing crops and activities of bacteria in an estuary during a Neap-Spring-Neap tidal cycle. Oceologia 24: $83-90$

Goulder, R. (1977). Attached and free bacteria in an estuary with abundant suspended solids. J. appl. Bact. 43: $399-405$

Goulder, R., Blanchard, A. S., Sanderson, P. L., Wright, B. (1979). A note on the recognition of pollution stress in populations of estuarine bacteria. J. appl. Bact. 46: 285-289

Goulder, R., Blanchard, A. S., Sanderson, P. L., Wright, B. (1980). Relationships between heterotrophic bacteria and pollution in an industrialized estuary. Water Res. 14: 591-601

Grieve, D., Flechter, K. (1977). Interactions between zinc and suspended sediments in the Fraser River Estuary, B. C. Estuar coast. mar. Sci. 5: 415-419

Griffiths, R. P., Hayasaka, S. S., McNamara, T M., Morita, R. Y. (1978). Relative microbial activity and bacterial concentrations in water and sediment samples taken in the Beaufort Sea. Can. J. Microbiol. 24: 1217-1226

Hanson, R. B., Wiebe, W. J. (1977). Heterotrophic activity associated with particulate size fractions in a Spartina alterniflora salt-marsh estuary, Sapelo Island, Georgia, USA and the continental shelf waters. Mar. Biol. 42: 321-330

Harrison, M. J., Wright, R. T., Morita, R. Y. (1971). Method for measuring mineralization in lake sediments. Appl. Microbiol. 21: 698-702

Hobbie, J. E., Crawford, C. C. (1969a). Respiration corrections for bacterial uptake of dissolved organics in natural waters. Limnol. Oceanogr. 14: 528-532

Hobbie, J. E., Crawford, C. C. (1969b). Bacterial uptake of organic substrate: New methods of study and application to eutrophication. Verh. int. Verein. theor angew. Limnol. 17: $725-730$

Hobbie, J. E., Daley, R. J., Jasper, S. (1977). Use of Nuclepore filters for counting bacteria by fluorescent microscopy. Appl. environ. Microbiol. 33: 1225-1228

Holm-Hansen, O., Booth, C. R. (1966). The measurement of adenosine triphosphate in the ocean and its ecological significance. Limnol. Oceanogr 11: 510-519

Holm-Hansen, O. (1973). Determination of total microbial biomass by measurement of adenosine triphosphate. In: Stevenson, L. H., Colwell, R. R. (eds.) Estuarine microbia] ecology. The Belle W Branch Library in Marine Science (University of South Carolina Press) No. 1, pp. 73-89

Hoppe, H.-G. (1978). Relations between active bacteria and heterotrophic potential in the sea. Neth. J. Sea Res. 12 (1): $78-98$

Jannasch, H. W (1956). Vergleichende bakteriologische Untersuchung der Adsorptionswirkung des Nil-Treibschlammes. Ber. limnol. Flusstn Freudenthal 7: 21-27

Konings, W. H., Veldkamp, H. (1980). Phenotypic responses to environmental change. In: Ellwood, D. C., Hedger, J. N., Latham, M. J., Lynch, J. M., Slater, J. H. ieds.) Contemporary microbial ecology. Academic Press, London, pp. $161-192$

Lenz, J. (1977). Seston and its main components. In: Rheinheimer, G. (ed.) Microbial ecology of a brackish water envoronment. Springer, Heidelberg, pp. 37-60

Meadows, P. S., Anderson, J. G. (1966). Microorganisms attached to marine and freshwater sand grains. Nature, Lond. 212: $1059-1060$ 
Milliman, J. D. (1980). Sedimentation in the lower Fraser River and its estuary, Southwestern British Columbia (Canada). Estuar. coast. mar Sci. 10: 609-633

Mitchell, R. (1968). Factors affecting the decline of nonmarine microorganisms in seawater Wat. Res. 2: 535-543

Moss, B. (1970). Seston composition in two freshwater pools. Limnol. Oceanogr 15 (4): 504-513

Odum, E. P., De La Cruz, A. A. (1967). Particulate organic detritus in Georgia salt marsh-estuarine ecosystem. In: Lauff, G. H. (ed.) Estuaries. Publs Am. Ass. Advmt Sc1. 83: $383-388$

Overbeck, J., Daley, R. J. (1973). Some precautionary comments on the Romanenko technique for estimating heterotrophic bacterial production. Bull. Ecol. Res. Comm. 17: 342-344

Palumbo, A. V., Ferguson, R. L. (1978). Distribution of suspended bacteria in the Newport River Estuary, North Carolina. Estuar coast. mar Sci. 7: 521-529

Parsons, T. R., Stephens, K., Le Brasseur, R. J. (1969). Production studies in the Strait of Georgia, Part I. Primary production under the Fraser River plume, February to May 1967. J. mar. biol. Ecol. 3: 27-38

Riemann, B. (1978). Differentiation between heterotrophic and photosynthetic plankton by size fractionation, glucose uptake, ATP and chlorophyll a content. Oikos 31: 358-367

Romanenko, V I., Overbeck, J., Sorokin, Y I. (1972). Estimation of production of heterotrophic bacteria using ${ }^{14} \mathrm{C}$. In: Sorokin, Y I., Kadota, H. (eds.) Microbial production and decomposition in fresh waters. Blackwell, Oxford, pp. $82-85$

Roper, M. M., Marshall, K. C. (1979). Effects of salinity on sedimentation and of particulates on survival of bacteria in estuarine habitats. Geomicrobiol. J. 1 (2): 103-116

Seki, H., Stephens, K. V., Parsons, T. R. (1969). The contribution of allochthonous bacteria and organic materıals from a small river into a semi-enclosed sea. Archiv. Hydrobiol. 66 (1): $37-47$

Seki, H., Yamaguchi, Y., Ichimura, S. (1975). Turnover rate of dissolved organic materials in a coastal region of Japan at summer stagnation period of 1974. Archiv. Hydrobiol. 75 (3): $297-305$

Sheldon, R. W (1972). Size separation of marine seston by membrane and glass-fiber filters. Limnol. Oceanogr. 17: 494-498

Sieburth, J. MCN., Brooks, R. D., Gessner, R. V., Thomas, C. D., Tootle, J. L. (1974). Microbial colonization of marine plant surfaces as observed by scanning ekotron microscopy. In: Colwell, R. R., Mortia, R. Y (eds.) Effect of the ocean environment on microbial activities. Baltimore, University Park Press, pp. 418-432

Stainton, M. P. (1973). A syringe gas stripping procedure for gas chromatographic determination of dissolved inorganic and organic carbon in freshwater and carbonates in sediment. J. Fish. Res. Bd Can. 30: 1441-1445

Steele, J. H., Baird, I. E. (1965). The chlorophyll a content of particulate organic matter in the Northern North Sea. Limnol. Oceanogr. 10 (2): 261-267
Stevenson, L. H., Erkenbrecher, C. W. (1976). Activity of bacteria in the estuarine environment. In: Wiley, M. (ed.) Estuarine processes, Vol. 1, Uses, stresses and adaptations to the estuary. Academic Press, New York, pp. 381-394

Stockner, J. G., Cliff, D. D., Shortreed, K. R. S. (1974). Phytoplankton ecology of the Strait of Georgia, British Columbia. J. Fish. Res. Bd Can. 36: 657-666

Strickland, J. D. H., Parsons, T R. (1968). A practical handbook of sea-water analysis. Bull. Fish. Res. Bd Can. 167: $1-311$

Takahashi, M., Fujii, K., Parsons, T R. (1973). Simulation study of phytoplankton photosynthesis and growth in the Fraser River estuary. Mar. Biol. 19: 102-116

Tison, D. L., Pope, D. H. (1980). Effect of temperature on mineralization by heterotrophic bacteria. Appl. environ. Microbiol. 3 (3): 584-587

Vaccaro, R. F., Jannasch, H. W. (1966). Studies on heterotrophic activity in sea-water based on glucose assimilation. Limnol. Oceanogr. 11: 596-607

Valdes, J. M. (1980). Activities and biomasses of bacterioplankton within the Fraser River Estuary. M. Sc. thesis, Simon Fraser University, Burnaby, British Columbia, Canada

Watson, S. W., Novitsky, T. J., Quinby, H. L., Valois, F. W (1977). Determination of bacterial number and biomass in the marine environment. Appl. environ. Microbiol. 33 (4): 940-946

Watson, T G. (1970). Effects of $\mathrm{NaCl}$ on stady state growth and metabolism of Saccharomyces cerevisiae. J. gen. Microbiol. 64: 91-99

Weber, C. I. (1973). Recent developments in the measurement of the response of plankton and periphyton to changes in their environment. In: Glass, G. E. (ed.) Bioassay techniques and environmental chemistry. Ann Arbor Science Publishers, Ann. Arbor, Michigan, pp. 119-138

Wiebe, W. J., Pomeroy, L. R. (1972). Microorganisms and their association with aggregates and detritus in the sea: $A$ microscopic study. In: Detritus and its role in aquatic ecosystems. Memorie Ist. ital. Idrobiol. 29 (Suppl.): 325-352

Wood, L. W., Chua, K. E. (1973). Glucose flux at the sedimentwater inferface of Toronto Harbour, Lake Ontario, with reference to pollution stress. Can. J. Microbiol. 19: $413-420$

Wright, R. T., Hobbie, J. E. (1966). Use of glucose and acetate by bacteria and algae in aquatic ecosystems. Ecology 47 : $447-464$

Wright, R. T., Shah, H. M. (1975). The trophic role of glycollic acid in coastal waters. I. Heterotrophic metabolism in seawater and bacterial cultures. Mar. Biol. 33: 175-183

Wright, R. T. (1978). Measurement and significance of specific activity in the heterotrophic bacteria of natural waters. Appl. environ. Microbiol. 36 (2): 297-305

Zeitzschel, R. (1970). The quantity, composition and distribution of suspended particulate matter in the Gulf of California. Mar. Biol. 7: 305-318 